\title{
Influence of diet and microbial activity in the digestive tract on digestibility, and nitrogen and energy metabolism in rats and pigs
}

\author{
By B. O. EGGUM, GRETE THORBEK, R. M. BEAMES*, A. CHWALIBOG \\ AND S. HENCKEL
National Institute of Animal Science, Department of Animal Physiology and Chemistry, Rolighedsvej 25, DK-1958 Copenhagen, Denmark

(Received 25 June 1981-Accepted 12 March 1982)

\begin{abstract}
1. Balance trials with respiration measurements were performed with twelve rats and twelve pigs given either low- or high-crude-fibre diets. There were six collection periods with the rats over a live-weight range of $86-264 \mathrm{~g}$ and three collection periods with the pigs over a live-weight range of 30-55 kg. Measurements were made on the influence of microbial activity in the digestive tract on digestibility and nitrogen and energy metabolism. Dietary inclusion of the antibiotic Nebacitin was the method used to reduce the microbial population.

2. The microbial activity in the hind-gut ( $\mu \mathrm{mol}$ ATP/g air-dry contents) of antibiotic-treated rats was reduced to approximately one-tenth of that of untreated rats.

3. Live-weight gain was not significantly affected in either species by a reduction in the microbial activity, in spite of a reduction in dry matter digestibility in animals with reduced microflora.

4. For rats on low-crude-fibre diets, a reduction in microflora reduced digestibility of all nutrients and energy and metabolizability of digestible energy by approximately $5.4 \%$. All differences were highly significant. On high-crude-fibre diets the decrease was approximately $5.9 \%$. In pigs on both crude fibre levels, the digestibility was also influenced by the level of microflora, but the pattern was somewhat different from that obtained with rats, with the Nebacitin treatment increasing the digestibility of $\mathbf{N}$ slightly, and the digestibility of fat markedly.

5. Retained $\mathrm{N}$ in rats reached a maximum when the rats were approximately $60 \mathrm{~d}$ old and thereafter decreased with increasing age. However, for pigs daily $\mathbf{N}$ retention increased with age. The retained $\mathbf{N}$ : digested $\mathbf{N}$ value decreased linearly with age in the rats, but varied little with age over the range (104-146 d) studied in the pigs.

6. The metabolizability of gross energy (metabolizable energy (ME): gross energy) was significantly reduced with an increase in crude fibre level and by the addition of Nebacitin.

7. Retained energy (RE) in relation to ME (RE:ME), was not significantly affected either by level of microbial activity or by crude fibre.

8. The ratio, $R E$ as fat (RF): $R E$ as protein (RP) increased as the animals grew. In the rat experiment there was a tendency for RP to be higher for animals with normal microflora than for animals with reduced microflora for both crude fibre levels.

9. With rats, the regression analyses indicated that the energy requirement for maintenance could be influenced by both the level of microbial activity in the digestive tract and by the level of fibre in the diet. The net availability of ME for maintenance and growth by rats averaged 0.72 for all treatments.
\end{abstract}

10. The net availability of ME for growth in the pigs averaged 0.65 for all treatments.

There is no doubt that the presence of a population of micro-organisms in the alimentary tract of single-stomached animals can have a significant effect on digestibility of nutrients as well as on nitrogen and energy metabolism. Several experiments have shown that the intestinal flora can degrade amino acids, amides and urea (e.g. Michel, 1966; Mason \& Just, 1976) as well as carbohydrates (Mason, 1980). The metabolic activity of hind-gut micro-organisms is thus well documented, demonstrating that the type and extent of fermentation is strongly influenced by the efficiency with which food is digested and absorbed prior to the end of the small intestine, i.e. food components of low digestibility stimulate the rate of fermentation.

Fibre digestion is almost entirely confined to the large intestine (Farrell \& Johnson, 1972). However, starch digestion mainly occurs in the small intestine, but there are several

* Present address: Department of Animal Science, The University of British Columbia, Vancouver, BC, V6T 2A2, Canada. 
situations which encourage its degradation in the large intestine (Mason \& Just, 1976). Carbohydrate, irrespective of type, is degraded in the large intestine by micro-organisms to volatile fatty acids, lactic and other organic acids, carbon dioxide, methane and hydrogen.

In addition to their degradative activities, the microflora of the large intestine assimilate nitrogenous materials into their cell components (Fauconneau \& Michel, 1970). This assimilation is principally from ammonia, but peptides and amino acids can be utilized by some bacterial species (Payne, 1975). Moreover, it is known that faecal $\mathbf{N}$ excretion by single-stomached animals is influenced by the amount and type of fibre (Rerat, 1978) in addition to its responses to the type and quantity of dietary $\mathrm{N}$.

Although information on the form of the $\mathrm{N}$ absorbed from the large intestine is still incomplete, it appears that most is absorbed as ammonia (Hoover \& Heitmann, 1975). Undoubtedly, some of the ammonia arises from the degradation of urea. Studies using germ-free rats indicate that this compound diffuses into the alimentary canal in appreciable quantities (Combe \& Sacquet, 1966). Thus, net absorption of $\mathrm{N}$ in the hind-gut represents the balance between processes of degradation and assimilation attained by the microflora during the period of fermentation. It is thus evident that hind-gut bacteria, by influencing both digestibility and $\mathrm{N}$ excretion patterns, must also affect energy utilization. The practical significance of these changes has not been clearly defined in terms of the interaction between the level of fermentable fibre and protein passing beyond the terminal ileum.

Attempts have been made to determine whether antibiotics have any detectable effect on organisms of the intestinal tract, in addition to the suppression of those causing disease. In such an experiment, Eggum et al. (1979) demonstrated that the microbial activity in the hind-gut of rats could be reduced to one-fifth by the addition of $7 \mathrm{~g} \mathrm{Nebacitin} / \mathrm{kg}$ to the diet. Digestibility of protein, amino acids and energy were markedly reduced by this dietary treatment.

While it is known that VFA are the principal source of energy for ruminant animals, there is only limited information available on the extent to which bacterial fermentation contributes to the energy economy of rats and pigs. However, it is clear that VFA are produced in the hind-gut and that they appear to be readily absorbed and utilized by the animal (Kennelly \& Ahern, 1980). VFA certainly serve as a source of energy since ${ }^{14} \mathrm{CO}_{2}$ is found in the expired air when ${ }^{14} \mathrm{C}$-labelled VFA are introduced into the caecum (Yang et al. 1970) or when they are ingested (McAtee et al. 1967). However, acetic acid offered to rats in the form of triacetine has a $15 \%$ lower nutritive value than starch for growth and maintenance (Vermorel, 1968). Just (1980) showed that crude fibre depressed the amount and utilization of ME, which indicates a lower utilization of energy absorbed in the hind-gut (VFA) than energy absorbed in the small intestine (starch).

Tentative estimates have been made of the amount of energy available to the organisms through the products of fermentation in the large bowel (Mason, 1980). The results obtained are highly variable, with the variation mainly associated with the nature of the dietary carbohydrates and with the animal species. With cereal-based diets, $8-16 \%$ of the total organic matter digested in the tract might be absorbed from the hind-gut (Holmes $e t$ al. 1973; Mason \& Just, 1976; Sambrook, 1979). The rat seems to produce relatively more VFA in the caecum than the pig. This fact might be connected with differences between species in the relative volumes of the caecum and the large intestine (Yang et al. 1970).

From these findings it may be concluded that the products of the fermentation of cell wall components absorbed from the large intestine may contribute significantly to the net energy requirements of the single-stomached animal. These products may represent approximately $10 \%$ of the digestible energy in the pig, depending on dietary composition, and probably less in the rat, which has a relatively smaller hind-gut.

The present experiment was designed to investigate various aspects of the microbial 
activity in the gut on nutrient utilization. Grass meal was used to vary dietary crude fibre level and Nebacitin to reduce microbial activity. The treatments were applied to both rats and pigs to allow an interspecies comparison.

\section{MATERIALS AND METHODS}

Animals and diets

Twelve male specific-pathogen-free (SPF) Wistar rats and twelve castrated male pigs of Danish Landrace breed with initial live-weights of $60-70 \mathrm{~g}$ and $22-26 \mathrm{~kg}$, respectively, were allocated to four diets (A, B, C and D). The rats were randomly allocated. Within replicates, litter-mate pigs were randomly allocated. The diets consisted of barley, soya-bean meal and meat-and-bone meal (A and B) or with (C and D) the addition of grass meal to provide both a low level $(47 \mathrm{~g} / \mathrm{kg})$ and a high level $(105 \mathrm{~g} / \mathrm{kg})$ of crude fibre (Table 1). Crude protein $(\mathrm{N} \times 6.25)$ was kept at a low level in all diets $(130-133 \mathrm{~g} / \mathrm{kg})$ to be able to measure possible differences in dietary protein quality. With a gross energy content of $15.8 \mathrm{MJ} / \mathrm{kg}$ in all diets, this corresponds to $750 \mathrm{~kJ} / \mathrm{g} \mathrm{N}$. Nebacitin (Bacitracin-Neomycin sulphate $2: 1, \mathrm{w} / \mathrm{w}$ ) was purchased from 'Apodan', Englandsvej 382A, Copenhagen. The antibiotics were added to diets $B$ and $D$ at a level of $7 \mathrm{~g} / \mathrm{kg}$ in order to reduce the microflora content in the gut. All nutrient concentrations are expressed on a fresh matter basis.

\section{Experimental procedure}

Rats. All rats were kept individually in metabolism cages for the whole of the experimental period of $56 \mathrm{~d}$. After a preliminary period, six consecutive balance periods, each consisting of a $7 \mathrm{~d}$ collection of faeces and urine were carried out to determine digestibility of dry matter (DM), organic matter, $\mathrm{N}$, crude fat, crude fibre and energy, and the metabolism of $\mathrm{N}$ and energy. Feed was restricted to $14 \mathrm{~g} / \mathrm{d}$ in period $1,20 \mathrm{~g} / \mathrm{d}$ in period 2 and $21 \mathrm{~g} / \mathrm{d}$ in periods 3-6 inclusive. At all times there was free access to water. The diets were ground and mixed to prevent separation of ingredients. Techniques used for separate collection of faeces and urine and methods of chemical analyses conformed with standard procedures at the

Table 1. Composition and analysis $(\mathrm{g} / \mathrm{kg})$ of experimental diets used for both rats and pigs

\begin{tabular}{|c|c|c|c|c|}
\hline \multirow{2}{*}{$\begin{array}{l}\text { Crude fibre level... } \\
\text { Microflora status... } \\
\text { Diet... }\end{array}$} & \multicolumn{2}{|c|}{ Low } & \multicolumn{2}{|c|}{ High } \\
\hline & $\begin{array}{c}\text { Normal } \\
A\end{array}$ & $\underset{\text { B }}{\text { Reduced }^{*}}$ & $\underset{C}{\text { Normal }}$ & $\begin{array}{l}\text { Reduced } \\
\text { D }\end{array}$ \\
\hline Barley & \multicolumn{2}{|c|}{894} & \multicolumn{2}{|c|}{613} \\
\hline Soya-bean meal & \multicolumn{2}{|c|}{40} & \multicolumn{2}{|c|}{33} \\
\hline Meat-and-bone meal & \multicolumn{2}{|c|}{17} & \multicolumn{2}{|c|}{14} \\
\hline Grass meal & \multicolumn{2}{|c|}{0} & \multicolumn{2}{|c|}{283} \\
\hline $\mathrm{CaCO}_{3}$ & \multicolumn{2}{|c|}{19} & \multicolumn{2}{|c|}{15} \\
\hline $\mathrm{Na}_{2} \mathrm{HPO}_{4}$ & \multicolumn{2}{|c|}{24} & \multicolumn{2}{|c|}{36} \\
\hline $\mathrm{NaCl}$ & \multirow{2}{*}{\multicolumn{2}{|c|}{5}} & \multicolumn{2}{|c|}{5} \\
\hline Vitamin-supplement $\dagger$ & \multirow{2}{*}{\multicolumn{2}{|c|}{$\begin{array}{r}1 \\
871\end{array}$}} & \multicolumn{2}{|c|}{1} \\
\hline Dry matter & & & \multicolumn{2}{|c|}{872} \\
\hline Crude protein (nitrogen $\times 6.25$ ) & \multicolumn{2}{|c|}{$\begin{array}{l}871 \\
130\end{array}$} & \\
\hline Crude fibre & \multicolumn{2}{|c|}{47} & \multicolumn{2}{|c|}{105} \\
\hline Crude fat & \multicolumn{2}{|c|}{28} & \multirow{2}{*}{\multicolumn{2}{|c|}{$\begin{array}{l}30 \\
15.8\end{array}$}} \\
\hline Gross energy (MJ/kg) & \multicolumn{2}{|c|}{15.8} & & \\
\hline
\end{tabular}

- Reduced microflora status was obtained by a supply of $7 \mathrm{~g}$ Nebacitin (Bacitracin-Neomycin sulphate 2: $\mathrm{l}$, $w / w) / k g$ diet.

+ The vitamin supplement provided $(\mathrm{mg} / \mathrm{kg}$ diet) : retinol $1 \cdot 5$, cholecalciferol $0 \cdot 17, \alpha$-tocopherol $12 \cdot 5$, riboflavin $2 \cdot 5$, pyridoxine $10 \cdot 0$, cyanocobalamin $0 \cdot 0125$, pantothenic acid $10 \cdot 0$. 
Institute, as described by Eggum (1973). A $24 \mathrm{~h}$ respiration experiment was performed in the middle of each collection period in order to measure carbon balance, except in the first period where, for technical reasons, no respiration measurements took place. Respiration chambers with open-air circulation as described by Chwalibog et al. (1979) were used to measure the gas exchange on each group of three rats. The oxygen $\left(\mathrm{O}_{2}\right)$ consumption and $\mathrm{CO}_{2}$ production for each group of rats was divided in proportion to individual metabolic live-weights ( $\mathrm{kg}$ live-weight $\mathrm{t}^{0.75}$ ) to allow calculation of energy metabolism on an individual basis.

Pigs. The animals were kept individually in pens or metabolism crates throughout the 72 d experiment, which incorporated three balance periods, each consisting of a preliminary period of $14 \mathrm{~d}$ followed by a collection period of $7 \mathrm{~d}$. Food allowances were restricted to 1200,1600 and $2000 \mathrm{~g} / \mathrm{d}$ in periods 1,2 and 3, respectively. The food components, coarsely milled, were weighed out separately in individual bags. These components were mixed with three times their weight of water just before feeding in order to obviate problems with food residues. Extra water was offered if required. A $24 \mathrm{~h}$ respiration experiment was performed in the middle of each collection period to determine $C$ balance. Respiration chambers with open-air circulation as described by Thorbek (1969) were used to measure the individual $\mathrm{O}_{2}$ consumption and $\mathrm{CO}_{2}$ production. Procedures for collection of faeces and urine were those described by Thorbek (1975). The experiment started when the pigs were approximately 14 weeks old with a mean live-weight of approximately $30 \mathrm{~kg}$. The experiment was concluded when the pigs were approximately 21 weeks old with a live-weight ranging from 52 to $55 \mathrm{~kg}$ for the pigs on diets $\mathrm{A}$ and $\mathrm{B}$, and from 48 to $50 \mathrm{~kg}$ for the pigs on diets $\mathrm{C}$ and $D$.

\section{Analytical methods}

All chemical analyses including calorimetry of food components, faeces and urine were done by the methods described by Weidner \& Jakobsen (1962) except for the fat determination, where the samples were hydrolysed with hydrochloric acid before the extraction with diethyl ether according to Stoldt (1952). Carbon determination was carried out by means of a Wösthoff instrument as described by Neergaard et al. (1969). The composition of the outgoing air from the respiration chambers was measured with a Uras instrument (infra-red principle) for $\mathrm{CO}_{2}$ and with a Magnos instrument (paramagnetic principle) for $\mathrm{O}_{2}$ as described by Thorbek (1969). ATP in the intestinal contents of rats was estimated as described by Wolstrup \& Jensen (1976). Constants and factors used for calculating the energy metabolism were those given by Brouwer (1965). Statistical analyses were based on Hald (1952).

\section{RESULTS}

Food intake and live-weight

The age, food intake and live-weight of rats are shown in Fig. 1. The values are means for the middle of each period. With the restricted feeding system there were no food refusals. For the whole of the experimental period growth was lowest on the diets containing the higher levels of fibre, being $133 \pm 4.9 \mathrm{~g}$ on diet $\mathrm{C}$ which contained no antibiotic and $125 \pm 5.8 \mathrm{~g}$ on diet $\mathrm{D}$ with added antibiotic. With the low-crude-fibre diets, total live-weight gains were $167 \pm 5.8 \mathrm{~g}$ with no antibiotics (diet $\mathrm{A}$ ) and $172 \pm 4.1 \mathrm{~g}$ with antibiotics (diet B). The addition of antibiotics to the diet had no significant ( $t$ test, $P>0.05$ ) effect on live-weight gain at either level of fibre addition.

The results from the experiment with pigs are shown in Fig. 2. With restricted food intake, as in the experiment with rats, no food refusals occurred. Growth rate was lowest on the high-crude-fibre diets, $C$ and $D$. The mean live-weight gains on diets $A$ and $B$ (low-crude-fibre) were $21.9 \pm 0.8 \mathrm{~kg}$ and $23.9 \pm 0.6 \mathrm{~kg}$, respectively, corresponding to 521 and $569 \mathrm{~g} / \mathrm{d}$. On 


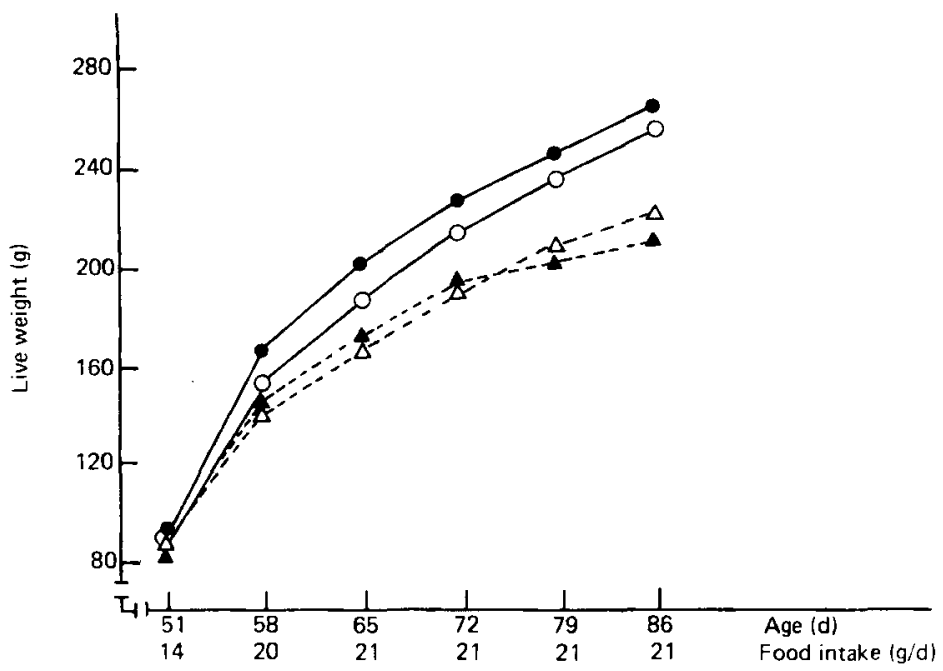

Fig. 1. Live-weight in relation to age and food intake by rats receiving four diets with or without antibiotic Nebacitin: $(\mathrm{O}-\mathrm{O})$, low-crude-fibre with normal microflora; $(\mathrm{O}-\mathrm{O})$, low-crude-fibre with reduced microflora; $(\Delta--\triangle)$, high-crude-fibre with normal microflora; $(\mathbf{\Delta}-\mathbf{\Delta})$, high-crude-fibre with reduced microflora.

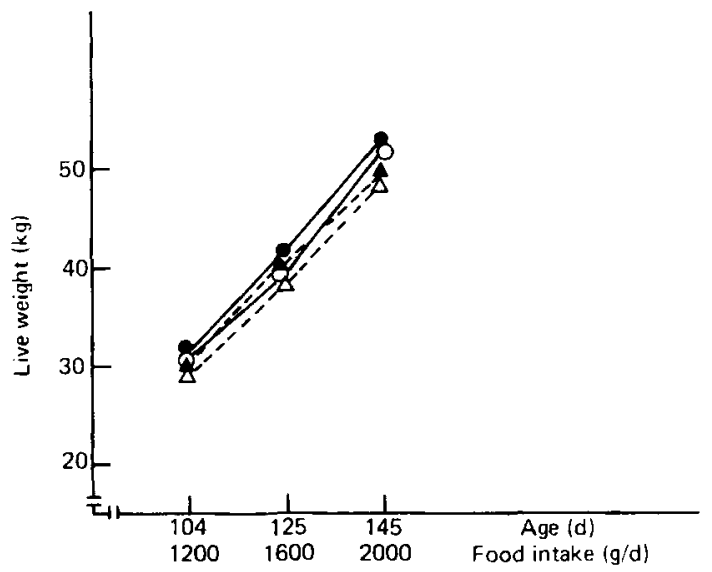

Fig. 2. Live-weight in relation to age and food intake by pigs receiving four diets with or without antibiotic Nebacitin: $(\mathrm{O}-\mathrm{O})$, low-crude-fibre with normal microflora; $(\mathrm{O}-\mathrm{O})$, low-crude-fibre with reduced microflora; $(\triangle--\Delta)$, high-crude-fibre with normal microflora; $\left(\boldsymbol{\Delta}^{--} \boldsymbol{\Delta}\right)$, high-crude-fibre with reduced microflora.

diets $C$ and $D$ the mean live-weight gains were $18 \cdot 2 \pm 1 \cdot 0 \mathrm{~kg}$ and $19 \cdot 0 \pm 1 \cdot 0 \mathrm{~kg}$, respectively, corresponding to 444 and $463 \mathrm{~g} / \mathrm{d}$. There was a tendency towards a higher live-weight gain on diets containing antibiotics at both crude fibre levels, but the differences were not significant ( $t$ test, $P>0.05$ ).

\section{Digestibility}

Values for the digestibility of proximate constituents and energy, together with the metabolizability of gross energy (ME:GE) for rats and pigs are presented in the Tables 2 and 3. 
Table 2. Digestibility coefficients and metabolizability (metabolizable energy: gross energy; $M E: G E)$ of diets by rats

(Mean values of six periods, each with three rats/diet)

\begin{tabular}{|c|c|c|c|c|c|c|c|}
\hline \multirow{2}{*}{$\begin{array}{l}\text { Crude fibre level... } \\
\text { Microflora status... } \\
\text { Diet... }\end{array}$} & \multicolumn{2}{|c|}{ Low } & \multicolumn{2}{|c|}{ High } & \multirow{2}{*}{$\begin{array}{c}\text { Total } \\
\text { pooled } \\
\text { SD } \\
\text { (df 68) }\end{array}$} & \multicolumn{2}{|c|}{$\begin{array}{c}\text { Statistical } \\
\text { significance } \\
\text { of differences }\end{array}$} \\
\hline & $\begin{array}{c}\text { Normal } \\
\text { A }\end{array}$ & $\begin{array}{c}\text { Reduced } \\
\text { B }\end{array}$ & $\begin{array}{c}\text { Normal } \\
\mathrm{C}\end{array}$ & $\begin{array}{l}\text { Reduced } \\
\text { D }\end{array}$ & & A v. B & Cv. D \\
\hline \multicolumn{8}{|l|}{ Digestibility } \\
\hline Dry matter & 0.814 & $0 \cdot 760$ & 0.664 & 0.609 & 0.0118 & $0 \cdot 054^{* * *}$ & $0.055^{* * *}$ \\
\hline Organic matter & 0.832 & 0.776 & 0.676 & 0.619 & 0.0127 & $0 \cdot 056^{* * *}$ & $0.057 * * *$ \\
\hline Nitrogen & 0.790 & 0.736 & 0.698 & 0.641 & 0.0133 & $0.054^{* * *}$ & $0 \cdot 057 * * *$ \\
\hline NFE & 0.895 & 0.841 & 0.794 & 0.734 & 0.0128 & $0.054^{* * *}$ & $0.060^{* * *}$ \\
\hline Crude fat & 0.688 & 0.652 & 0.575 & 0.559 & 0.0396 & $0.036^{* *}$ & $0.016 \mathrm{NS}$ \\
\hline Crude fibre & $0 \cdot 187$ & $0 \cdot 125$ & 0.080 & 0.012 & 0.0444 & $0.062^{* * *}$ & $0.068^{* * *}$ \\
\hline Gross energy & 0.814 & 0.756 & 0.654 & 0.600 & 0.0129 & $0.058^{* * *}$ & $0.054^{* * *}$ \\
\hline ME:GE & 0.804 & 0.744 & 0.642 & $0-588$ & 0.0122 & $0 \cdot 060^{* * *}$ & $0.054 * * *$ \\
\hline
\end{tabular}

NFE, N-free extract; NS, not significant $(P>0.05)$.

** $P<0.01, * * * P<0.001$.

Table 3. Digestibility coefficients and metabolizability (metabolizable energy: gross energy; $M E: G E)$ of diets by pigs

(Mean values of three periods, each with three pigs/diet)

\begin{tabular}{|c|c|c|c|c|c|c|c|}
\hline \multirow{2}{*}{$\begin{array}{l}\text { Crude fibre level... } \\
\text { Microflora status... } \\
\text { Diet... }\end{array}$} & \multicolumn{2}{|c|}{ Low } & \multicolumn{2}{|c|}{ High } & \multirow{2}{*}{$\begin{array}{c}\text { Total } \\
\text { pooled } \\
\text { SD } \\
\text { (df 32) }\end{array}$} & \multicolumn{2}{|c|}{$\begin{array}{c}\text { Statistical } \\
\text { significance } \\
\text { of differences }\end{array}$} \\
\hline & $\begin{array}{c}\text { Normal } \\
\text { A }\end{array}$ & $\begin{array}{c}\text { Reduced } \\
\text { B }\end{array}$ & $\underset{C}{\text { Normal }}$ & $\begin{array}{c}\text { Reduced } \\
\text { D }\end{array}$ & & A v. B & Cv. D \\
\hline \multicolumn{8}{|l|}{ Digestibility } \\
\hline Dry matter & 0.797 & 0.770 & 0.676 & 0.621 & 0.0151 & $0.027^{* * *}$ & $0.055^{* * *}$ \\
\hline Organic matter & 0.830 & 0.798 & 0.709 & 0.647 & 0.0112 & $0.032^{* * *}$ & $0.062^{* * *}$ \\
\hline Nitrogen & 0.730 & 0.750 & 0.570 & 0.598 & 0.0318 & $-0.020 \mathrm{NS}$ & $-0.026 \mathrm{NS}$ \\
\hline NFE & 0.916 & 0.873 & 0.845 & 0.786 & 0.0082 & $0.043 * * *$ & $0.059 * * *$ \\
\hline Crude fat & $0 \cdot 350$ & 0.458 & 0.286 & 0.374 & 0.0510 & $-0 \cdot 108^{* * *}$ & $-0.088^{* * *}$ \\
\hline Crude fibre & $0 \cdot 240$ & $0 \cdot 134$ & 0.312 & 0.091 & 0.0506 & $0 \cdot 106^{* * *}$ & $0.221^{* * *}$ \\
\hline Gross energy & 0.803 & 0.777 & 0.675 & 0.625 & 0.0129 & $0.026 * * *$ & $0.050^{* * *}$ \\
\hline ME: GE & 0.776 & 0.752 & 0.647 & 0.603 & 0.0119 & $0.024 * * *$ & $0 \cdot 044^{* * *}$ \\
\hline
\end{tabular}

NFE, N-free extract; NS, not significant $(P>0.05)$.

$* * * P<0.001$

In the experiment with rats the total pooled SD values ( $\mathrm{df} 68$ ), indicating the precision of the measurements, were approximately $1.3 \%$ for the different nutrients and energy, except for digested crude fat and crude fibre where the pooled SD values were 4.0 and $4.4 \%$, respectively. The digestibility was strongly influenced by the level of microflora. On the low-crude-fibre diets a reduction in microfiora level decreased the digestibility of all nutrients and energy by approximately $5.4 \%$. ME: GE was reduced by approximately the same extent. All differences were highly significant $(P<0.001)$ except for the digestibility of crude fat $(P<0.01)$. On the high-crude-fibre diets the decrease was approximately $5.9 \%$ in most 


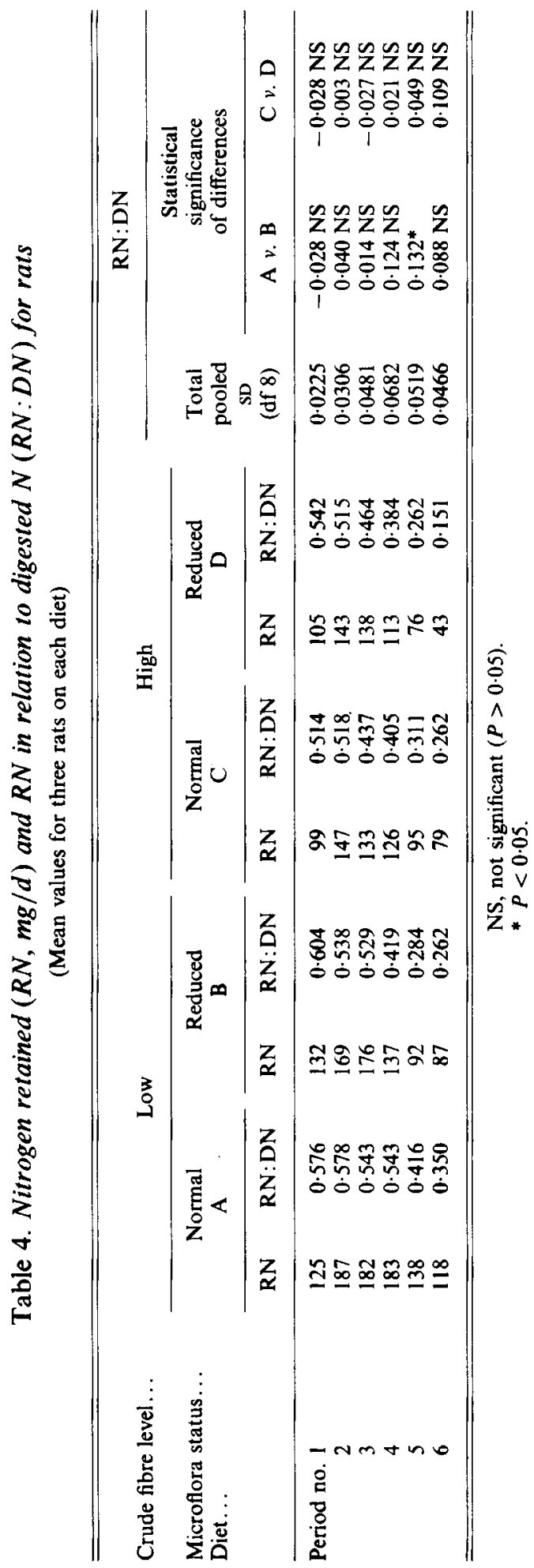


Table 5. Retained nitrogen $(R N, g / d)$ and $R N: D N$ in pigs

(Mean values of three pigs on each diet)

\begin{tabular}{|c|c|c|c|c|c|c|c|c|}
\hline \multirow{3}{*}{$\begin{array}{l}\text { Crude fibre level... } \\
\text { Microflora status... } \\
\text { Diet... }\end{array}$} & \multicolumn{4}{|c|}{ Low } & \multicolumn{4}{|c|}{ High } \\
\hline & \multicolumn{2}{|c|}{$\underset{A}{\text { Normal }}$} & \multicolumn{2}{|c|}{$\begin{array}{c}\text { Reduced } \\
\text { B }\end{array}$} & \multicolumn{2}{|c|}{$\begin{array}{c}\text { Normal } \\
\mathrm{C}\end{array}$} & \multicolumn{2}{|c|}{$\begin{array}{c}\text { Reduced } \\
\text { D }\end{array}$} \\
\hline & RN & RN:DN & RN & RN:DN & RN & RN:DN & $\mathrm{RN}$ & RN: DN \\
\hline Period no. 1 & 8.43 & 0.456 & $9 \cdot 01$ & 0.473 & $8 \cdot 36$ & 0.546 & $8 \cdot 31$ & 0.516 \\
\hline 2 & $11 \cdot 46$ & 0.463 & 11.62 & 0.457 & $9 \cdot 28$ & 0.491 & $10 \cdot 21$ & 0.532 \\
\hline 3 & $12 \cdot 60$ & 0.422 & 12.03 & 0.392 & $11 \cdot 49$ & 0.488 & $13 \cdot 17$ & 0.537 \\
\hline \multicolumn{9}{|c|}{$\mathrm{RN} v . \mathrm{DN}$} \\
\hline & Diet & $r$ & $s_{\mathrm{b}}$ & RSD & $\begin{array}{l}\mathrm{CV} \\
(\%)\end{array}$ & & & \\
\hline & A & 0.460 & 0.0079 & 0.426 & $4 \cdot 3$ & & & \\
\hline & B & 0.463 & 0.0055 & 0.304 & $2 \cdot 9$ & $>\mathrm{NS}$ & & \\
\hline & C & 0.501 & 0.0121 & 0.710 & $7 \cdot 3$ & $>\mathbf{N S}$ & & \\
\hline & D & 0.508 & 0.0114 & 0.636 & 6.4 & $>100$ & & \\
\hline \multicolumn{9}{|c|}{$\mathrm{f}$ (groupwise to total) $5 \cdot 868^{* *}$} \\
\hline
\end{tabular}

$r$, regression coefficient; $s_{\mathrm{b}}$, standard deviation of $r$, RSD, residual SD; CV, coefficient of variation; NS, not significant $(P>0 \cdot 05)$.

** $P<0.01$.

instances, all being highly significant $(P<0 \cdot 001)$, except for the digestibility of crude fat where the difference was only 0.016 and not significant $(P>0.05)$.

In the experiment with pigs the total pooled SD values ( $\mathrm{df} 32$ ) indicated the same precision in the measurements as those obtained in the experiment with rats. Although the digestibility was influenced by the level of microflora, the pattern was different from that obtained with rats. Digestibility of DM, OM, NFE, and GE, together with ME: GE decreased by approximately 0.030 on the low-crude-fibre diets and 0.054 on the high-crude-fibre diets as a result of a reduction in the microflora level, with highly significant $(P<0 \cdot 001)$ differences. The digestibility of $\mathrm{N}$ was slightly higher with a reduced microflora, but the difference was not significant $(P>0.05)$. The digestibility of crude fat significantly $(P<0.001)$ increased from 0.350 to 0.458 , and from 0.286 to 0.374 as a result of a reduction in the microflora level on the low-crude-fibre and the high-crude-fibre diets, respectively. In contrast a reduction in microflora level caused significant $(P<0.001)$ decreases in fibre digestibility of 0.106 on the low-crude-fibre diet and 0.221 on the high-crude-fibre diet.

\section{$N$ metabolism}

In the experiment with rats, seventy-two individual $\mathrm{N}$ balances were carried out. The mean values from three rats on each of the four diets in the six balance periods are shown in Table 4.

Changes in $\mathrm{N}$ retention with age followed the same pattern for all diets, increasing to a maximum in periods 2 and 3 at an age of approximately $60 \mathrm{~d}$. $\mathrm{N}$ retention was highest on diet $A(187 \mathrm{mg} \mathrm{N} / \mathrm{d})$ and lowest on $\operatorname{diet} \mathrm{D}(143 \mathrm{mg} \mathrm{N} / \mathrm{d})$. Thereafter $\mathrm{N}$ retention decreased with age until period 6 (age $86 \mathrm{~d}$ ) when the retention on diets $A$ and $D$ was 118 and $43 \mathrm{mg} \mathrm{N} / \mathrm{d}$, respectively. The utilization of digested $N$ (retained $N$ :digested $N$; RN:DN) decreased with age on all diets. There were no significant $(P<0.05)$ differences between diets $\mathrm{A}$ and $\mathrm{B}$, and diets $\mathrm{C}$ and $\mathrm{D}$ except for $\mathrm{A} v$. B in period $5(P<0.05)$. 
$\mathrm{N}$ balance results from the thirty-six individual balances with pigs are presented in Table 5. From an initial age of $104 \mathrm{~d}$ and live-weight $30 \mathrm{~kg}$ in period 1 to final age $146 \mathrm{~d}$ and live-weight $50 \mathrm{~kg}$ in period 3, mean RN increased from $8 \cdot 5$ to $12 \cdot 3 \mathrm{~g} / \mathrm{d}$. This low RN could be explained by the low protein concentration $(130-133 \mathrm{~g} / \mathrm{kg})$ in the diets. Regressions of RN v. DN indicated that the over-all utilization of $N$ was approximately 0.46 on the low-crude-fibre diets and approximately 0.51 on high-crude-fibre diets with the microflora status having no significant $(P>0.05)$ effect on these values.

\section{Energy metabolism}

The results from the measurements of ME and retained energy (RE) in both rats and pigs are shown in Table 6 . With the nearly constant restricted intake of GE in all periods of the experiment with rats, the decrease in the metabolizability of the diets as a result of the Nebacitin inclusion caused a decrease in ME and RE. The mean RE was $69 \cdot 2$ and $64.8 \mathrm{~kJ} / \mathrm{d}$ for diets $\mathrm{A}$ and $\mathrm{B}$, respectively, and 60.3 and $56.5 \mathrm{~kJ} / \mathrm{d}$ for diets $\mathrm{C}$ and $\mathrm{D}$, respectively. The differences caused by the microflora status in the rats were analysed by $t$ tests between rats in corresponding periods. The values appeared to be significantly $(P<0.001)$ different. The decrease in RE on each diet as the experiment progressed, was due to an increasing maintenance requirement with increasing body-weight in combination with rather constant ME intake.

In the experiment with pigs, where the feed intake increased from $1200 \mathrm{~g}$ in period 1 to $2000 \mathrm{~g}$ in period 3 with a corresponding increase in the intake of GE, the ME intake, and consequently, the highest RE was found on diet $A$ and the lowest on diet $D$, thus reflecting the differences between diets in ME: GE. The differences in RE caused by the microflora status in the pigs were analysed by $t$ tests between pigs in corresponding periods. The values were significantly $(P<0.001)$ different. The RE increased as the experiment progressed as a result of the ME allowance increasing at a larger rate than the maintenance requirement.

From the individual $\mathrm{N}$ and carbon balances the energy retained as protein and fat was calculated. The results are shown in Table 7.

In the experiment with rats the energy retained in protein (RP) followed the same pattern for all diets, increasing to a maximum in periods 2 and 3 , and then decreased when the rats approached an adult state. The digestibility of $\mathrm{N}$ was lower on the high-crude-fibre diets than on low-crude-fibre diets and was further reduced as a result of the lower microflora activity (see Table 2). Consequently, the energy retained as protein decreased more slowly with diet $\mathrm{A}$ than with diet $\mathrm{B}$. On the high-crude-fibre diets the retention was lower than on the corresponding low-crude-fibre diets, but the pattern was the same, with the greater reduction in RP on reduced microflora (diet D). Although these differences in RP would have influenced the energy retained as fat (RF), there seemed to be no regular pattern in the latter. Essentially, it seemed not to be affected by age. However, RF: RP increased with age, largely as a result of the changes in RP.

In the experiment with pigs, the increasing feeding level as the pigs grew resulted in increases in both the RP and the RF (Fig. 3). However, with the restricted protein intake limiting the protein gain, the increment of the fat gain was relatively high, causing an increasing value for RF:RP for all diets as the experiment progressed.

The values from the measurements of energy metabolism have been used to estimate net availability of ME for growth and maintenance in rats and for growth in pigs.

Net availability in rats was calculated from the regression $\mathrm{ME}(\mathrm{kJ}) / \mathrm{kg}$ live-weight $\mathrm{t}^{0-75} v$. $\mathrm{RE}(\mathrm{kJ}) / \mathrm{kg}$ live-weight ${ }^{0.75}$ for all four diets. The parallel equations gave the following intercepts:

$$
\begin{array}{ll}
\operatorname{diet} \text { A } 549 \pm 20.9 \mathrm{~kJ} / \mathrm{W}^{0.75}, & \operatorname{diet} \text { B } 482 \pm 19.0 \mathrm{~kJ} / \mathrm{W}^{0.75}, \\
\operatorname{diet} \text { C } 469 \pm 19.5 \mathrm{~kJ} / \mathrm{W}^{0.75}, & \operatorname{diet} \text { D } 408 \pm 18.9 \mathrm{~kJ} / \mathrm{W}^{0.75}
\end{array}
$$




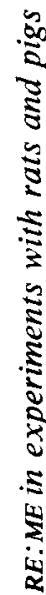

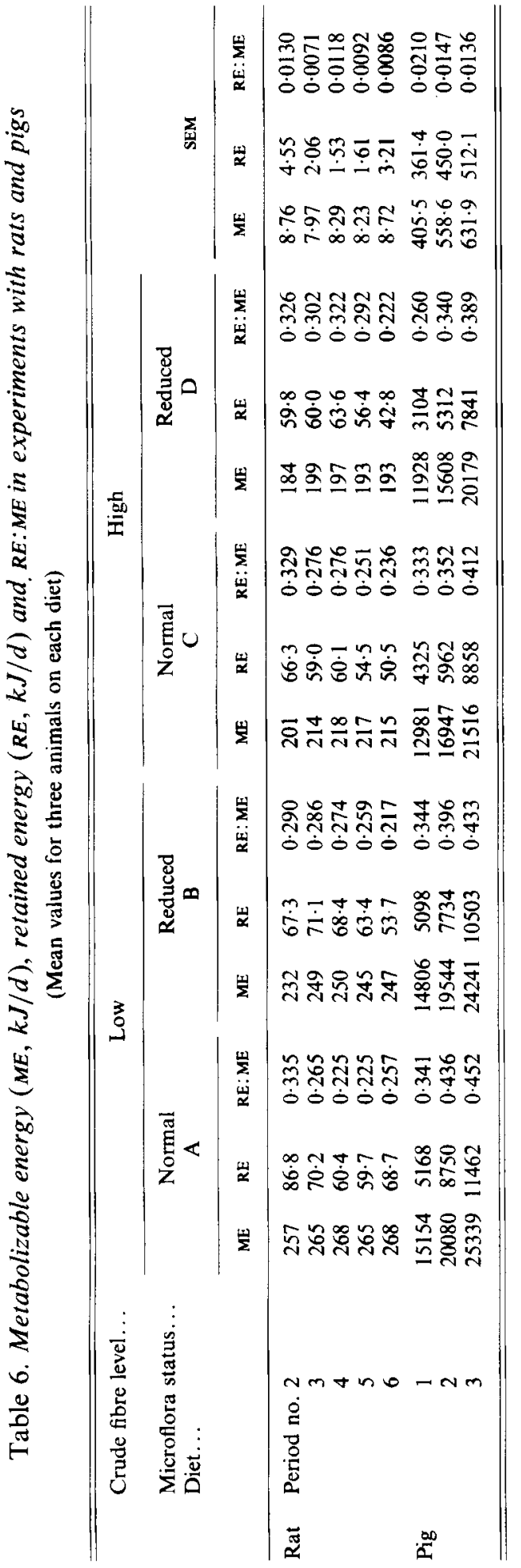

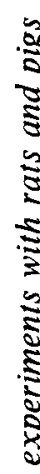

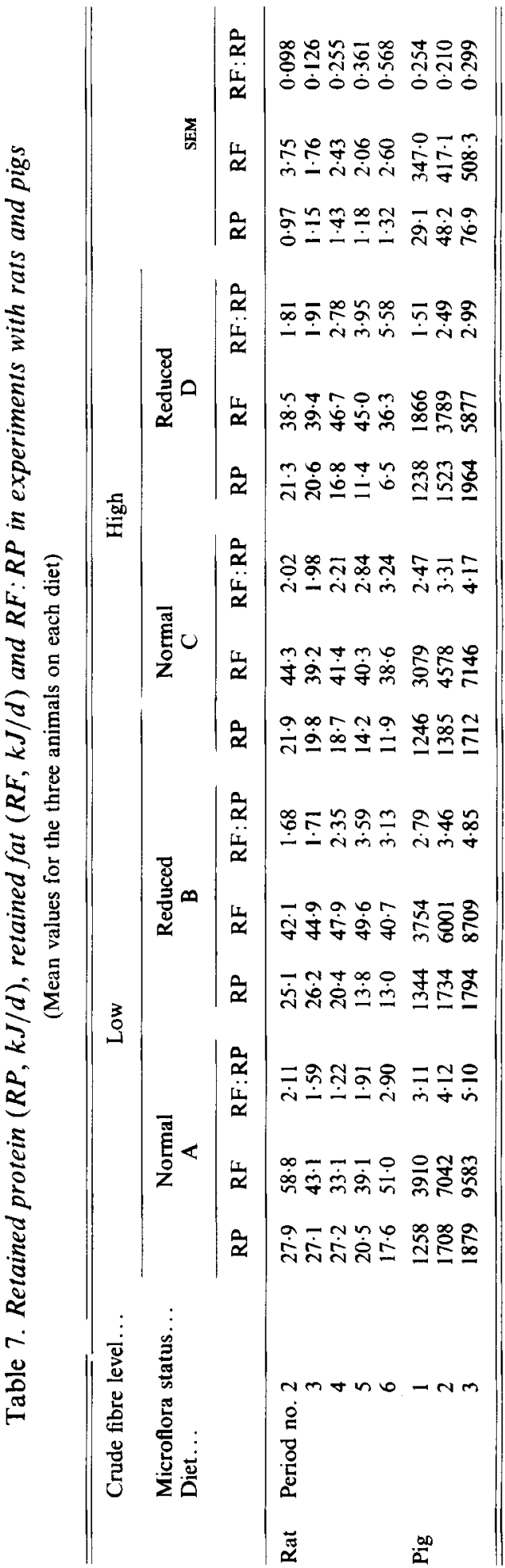




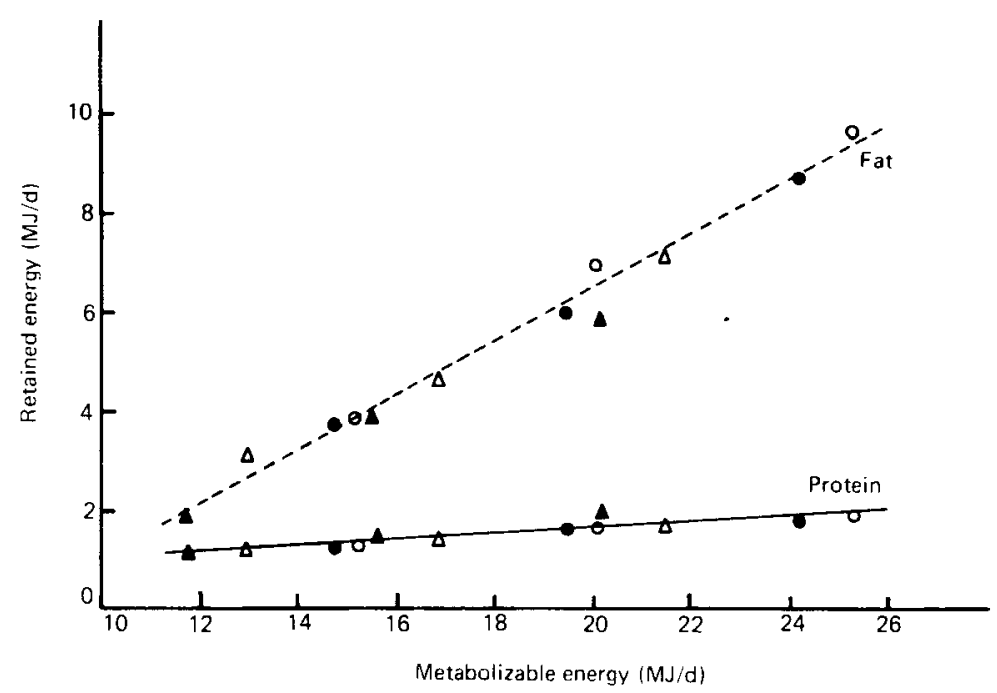

Fig. 3. Energy gained as protein (-) and as fat (--) by pigs of $30-55 \mathrm{~kg}$ live-weight receiving four diets: (O), low-crude-fibre, with normal microflora; $(O)$, low-crude-fibre, with reduced microflora; $(\triangle)$, high-crude-fibre, with normal microflora; (A), high-crude-fibre, with reduced microflora.

The equations gave a regression coefficient of $1 \cdot 39 \pm 0 \cdot 081 \mathrm{~kJ} / \mathrm{W}^{0.75}$ corresponding to a net availability of ME for growth of 0.72 for all diets.

In the pig experiment the data were used to calculate net availability of ME for growth $\left(k_{\mathrm{g}}\right)$ according to Thorbek \& Henckel (1976) by correcting the total ME for energy requirement for maintenance $\left(\mathrm{ME}_{\mathrm{m}}\right)$ where $\mathrm{ME}$ for growth $\left(\mathrm{ME}_{\mathrm{g}}\right)=\mathrm{ME}-\mathrm{ME}_{\mathrm{m}}$ and $\mathrm{ME}_{\mathrm{m}}$ $(\mathrm{kJ})=4060+210 \mathrm{~W}\left(\mathrm{~kg}\right.$ live-weight $\left.\mathrm{t}^{0 \cdot 75}\right)$. The regression RE $v$. ME was used with the following results ( $n 9$ for each diet):

$\begin{array}{ccc}\text { Diet } & k_{\mathrm{g}} & s_{\mathrm{b}} \\ \text { A } & 0.666 & 0.023 \\ \text { B } & 0.653 & 0.024 \\ \text { C } & 0.647 & 0.030 \\ \text { D } & 0.654 & 0.019\end{array}$

The obtained regression coefficients were compared by means of a $t$ test. No significant $(P>0.05)$ differences were found between the diets. Consequently all values were pooled and the total regression gave:

$$
\begin{gathered}
k_{\mathrm{g}} 0.654, \quad s_{\mathrm{b}} 0.017(n 36) . \\
\text { DISCUSSION }
\end{gathered}
$$

It should be stressed that the present work was done with SPF rats, but conventional (CV) pigs. Although it was shown in a previous experiment by Eggum (1972) that SPF rats digested protein $2-3 \%$ better than $\mathrm{CV}$ rats and produced a biological value which was approximately $5 \%$ better, the role of the gut microflora was not ascertained. However, digestible energy was similar when SPF rats were compared with CV pigs (Just et al. 1977). In the present work, even though the rats were SPF, microbial activity in the hind-gut was reduced by antibiotic treatment by approximately $90 \%$ as measured by ATP in hind-gut contents (Wolstrup \& Jensen, 1976). The corresponding measurement was not performed 
on the pigs as they were not slaughtered at the end of the experiment. However, the proportion of microbial protein in the faecal protein of the pigs was estimated, and will be reported in another paper in the same series.

Live-weight gain. Mean live-weight gain for both rats and pigs was significantly higher on the diets low in crude fibre (Figs. 1 and 2), as would be expected with all groups receiving the same air-dry feed allowance. However, live-weight gain was not significantly influenced by a reduction in the microbial activity, in spite of a significant reduction in DM digestibility in groups with this reduced activity. The results would thus indicate a higher utilization of absorbed energy in animals with a reduced microbial activity. This supports the findings of Rolls et al. (1978) which showed that CV birds have a more rapid turnover of epithelial cells than germ-free birds. This would, of necessity, have to influence energy metabolism. Based on results of Friend et al. (1963) and Etienne (1969), Mason (1980) calculated that the efficiency of production of organic acids by fermentation of glucose would have to lie within the range $72-85 \%$. Clearly, the greater the proportion of the total digestion that occurs in the large intestine the poorer will be the utilization of energy apparently digested by the host which will result in a lower live-weight gain.

Digestibility. The lower digestibility of the diets high in crude fibre for both rats and pigs is in agreement with observations made by several authors (e.g. Just Nielsen, 1970; Eggum, 1973). The reason for this is the limited capacity of single-stomached animals to digest fibrous materials.

Rats with RM had significantly lower digestibility values for all constituents (Table 2). This is in agreement with earlier results of Eggum et al. (1979), where similar reduced digestibilities were associated with reduced microbial activity, as indicated by the very low ATP values in the intestinal contents. As seen in Table 2, digestibility on the low-crude-fibre diets decreased by an average of approximately 0.054 for all nutrients and energy as well as for ME:GE as a result of reducing the microflora population. All differences were highly significant. On the high-crude-fibre diets the decrease was approximately 0.059 in most instances, except for crude fat; i.e. the microflora were able to account for the disappearance of $0.05-0.06$ of all dietary nutrients supplied to the rats.

In the experiment with pigs (Table 3 ) the digestibility was also significantly influenced by the level of microflora, but the pattern was somewhat different from that obtained with rats. In line with the results obtained with rats, digestibility of DM, organic matter, N-free extract and energy, together with the ME: GE decreased, although somewhat less than with rats, by reducing the microflora. However, the digestibility of $\mathrm{N}$ increased slightly in the reduced microflora treatments $B$ and $D$ although the difference was not significant. The same observations were made by Just et al. (1980) with pigs, who also found that $\mathrm{N}$ digestibility was unaffected by Nebacitin in the diets in spite of DM digestibility being significantly reduced. This might be explained by an improved absorption of $\mathbf{N}$ in the small intestine, due to the Nebacitin treatment, together with a reduced microbial protein synthesis in the hind-gut. However, there was a marked increase in apparent digestibility of crude fat by pigs with reduced microflora levels (diets $B$ and $D$ ). This can be explained by a significant microbial fat synthesis in pigs with normal microflora. This was also found by Mason \& Just (1976) with pigs. The much lower values for fat digestibility observed in the present work with pigs $(0.286-0.458)$ than in rats $(0.575-0.688)$ support the assumption that the $\mathrm{CV}$ pigs used in the present work were not as 'clean' as the SPF rats. The antibiotic treatment could apparently not prevent microbial fat synthesis in the pigs. However, the marked reduction in crude fibre digestibility in reduced microflora pigs indicates that there was a significant decrease in cellulolytic bacteria. By comparing the corresponding values obtained with rats with a normal microflora, it appears that the pigs have a much higher ability to digest crude fibre. The same was also the situation with animals with a reduced 
microflora, but the differences were not so marked. This again supports the assumption that, regardless of the level of antibiotic treatment in pigs, the microbial activity was relatively higher than in rats. However, the differences might be connected with differences between species in the relative volumes of the caecum and the large intestine (Yang et al. 1970). Although it may be unrealistic to expect identical values in such a comparison, Eggum (1973) in work with $\mathrm{CV}$ rats and $\mathrm{CV}$ piglets was unable to detect any species differences in protein and amino acid digestibilities for fifteen different protein sources. Digestible energy in fifty-eight food-stuffs was also similar when SPF rats were compared with CV pigs (Just et al. 1977). However, in the present work the values for dry matter digestibility obtained for rats and pigs, respectively, were also similar when corresponding diets were compared. This was the case irrespective of the microbial level in the digestive tract of the two animal species.

$N$ metabolism. As it can be seen from Table 4, RN in rats reached a maximum when the rats were approximately $60 \mathrm{~d}$ old, and thereafter decreased with increasing age. This clearly demonstrates the importance of using rats of the same age (body-weight) when protein quality tests are performed. RN:DN decreased linearly with age for rats on all four diets while the Nebacitin treatment had no significant influence on this value except in period 5 on the low-crude-fibre diets. However, there was a general tendency to lower RN:DN values in rats with reduced microflora. This is rather surprising as one would have expected that rats with a normal microflora might have absorbed some ammonia (of no protein value) from the hind-gut (Zebrowska et al. 1980 ) with a consequent increase in urinary $\mathrm{N}$ excretion.

RN: DN of pigs (Table 5) was very little affected by age in the live-weight range of $30-50 \mathrm{~kg}$ which was studied. Furthermore, it was not significantly affected by the level of microflora, which was also the situation with rats.

The protein concentration in the diets was kept low to maintain sensitivity to dietary protein quality. In spite of this, neither the results from rats nor from pigs indicated any significant absorption of non-protein $\mathrm{N}$ in animals with normal microbial activity.

Energy metabolism. As discussed above both rats and pigs had significantly higher live-weight gains on the diets low in crude fibre than on the diets high in crude fibre. This was to be expected, as gross energy allowances of all diets were equal, yet single-stomached animals have a limited capacity to digest diets high in cell wall constituents, as seen by the lower ME intakes on the high-crude-fibre diets. However, live-weight gain was not significantly influenced by a reduction in microbial activity. This indicates the possibility of a higher utilization of absorbed energy in animals with reduced microbial activity, and thus supports the hypotheses of lower energy value of nutrients absorbed in the hind-gut than the fore-gut (Vermorel, 1968; Just, 1980).

It is usually assumed that starch is digested in the small intestine and absorbed as monosaccharides, while VFA originate from fermentation in the hind-gut. Clearly the greater the proportion of the total digestion that occurs in the hind-gut the poorer will be the utilization of the energy apparently digested by the host.

By comparing the values for RE:ME in Table 6 a trend can be seen, indicating that pigs receiving a high-crude-fibre diet had a lower retention of ME than pigs given a low-crude-fibre diet. However, the differences were not significant $(P>0.05)$. The same tendency could not be seen in rats. However, as it can be seen in Table 7, there was no consistency between periods within diets in RF:RP. As discussed by Thorbek (1975), the utilization of ME for fat synthesis $(0.77)$ and the utilization for protein synthesis $(0.50)$ differ significantly. This makes it difficult to use RE: ME as an accurate indicator of relative absorption of the various forms of non-protein energy (carbohydrate and VFA). The situation is demonstrated in the rat experiment (Table 7) where the animals on high-crude-fibre diets retained relatively more energy as fat than as protein compared to animals on the low-crude-fibre diets. All else being 
equal, one would have expected the higher crude protein: ME value on the high-crude-fibre diets to have resulted in leaner carcasses.

Animals with reduced microbial activity, in accordance with their significantly lower organic matter digestibility, tended to retain less energy in relation to ME, than animals with normal microbial activity. The limited experimental data in the present work could not confirm a possible lower utilization of ME in animals with normal microbiological activity in the digestive tract compared to animals with reduced microbial activity.

Net availability of energy for growth measured on rats was 0.72 for all four diets, which is in the range of the values $(0 \cdot 70-0.78)$ of Hoffmann \& Schiemann (1977). However, the equations for RE/live-weight ${ }^{0.75} v$. ME/live weight $t^{0.75}$ in the present paper had different intercepts, indicating different requirements of ME for maintenance. Rats with reduced microflora seemed to have a lower energy requirement for maintenance than animals with normal microflora. However, due to the variation in RF: RP between diets, this way of estimating energy requirement for maintenance has been questioned (Henckel, 1976). These results support the findings of Rolls et al. (1978) with poultry, which showed conventional birds to have a more rapid turnover of epithelial cells than germ-free birds. This turnover would influence energy metabolism, as recently shown by Charlet-Lery et al. (1980), who observed higher energy retention in germ-free chickens due to a lower maintenance requirement.

In the pig experiment, $k_{\mathrm{g}}$ did not differ significantly between diets when ME was corrected by a constant factor for maintenance based on body-weight. The calculated $k_{\mathrm{g}}$ was of the same magnitude as that found in earlier work by Thorbek (1975). This supports our earlier assumption that the reduction in microbial activity as a result of the inclusion of Nebacitin in the diet was not as large in the pigs as in the rats.

The authors are most indebted to the Danish Agricultural and Veterinary Research Council for financial support.

\section{REFERENCES}

Brouwer, E. (1965). 3rd Eur. Ass. Anim. Prod. Symp. Energy Metabolism, Troon. London: Academic Press. Charlet-Lery, G., Szylit, O. \& Bewa, H. (1980). Publs. Eur. Ass. Anim. Prod. 26, 81.

Chwalibog, A., Lind, J. \& Thorbek, G. (1979). Z. Tierphysiol. Tierernähr. Futtermittelk, $41,154$.

Combe, E. \& Sacquet, E. (1966). C.r. Acad. Sci. 262, 685.

Eggum, B. O. (1972). Z. Tierphysiol. Tierernähr. Futtermittelk. 30, 172.

Eggum, B. O. (1973). Natl Inst. Anim. Sci. Copenhagen. beretn 406.

Eggum, B. O., Fekadu, M.. Wolstrup, J., Sauer, W. C. \& Just, A. (1979). J. Sci. Fd Agric. 30, 177.

Etienne, M. (1969). Journées de la Rech. Porcine en France. Paris. I.N.R.A., I.T.P. Ed. 13I. Quoted by Rerat, A. (1978). J. Anim. Sci. 46, 1808

Farrell, D. J. \& Johnson, K. A. (1972). Anim. Prod. 14, 209.

Fauconneau, G. \& Michel, M. (1970). In Mammalian Protein Metabolism [H. N. Munroe, editor]. New York: Academic Press.

Friend, D. W., Cunningham, H. M. \& Nicholson, J. W. G. (1963). Can. J. Anim. Sci. 34, 156.

Hald, A. (1952). Statistical Theory with Engineering Applications. New York-London: Wiley.

Henckel, S. (1976). Publs. Eur. Ass. Anim. Prod. Symp. Energy Metabolism, Vichy. 19, 145.

Hoffmann, L. \& Schiemann, R. (1977). Arch. Tierernähr. 27, 243.

Holmes, J. H. G., Bayley, H. S. \& Horney, F. D. (1973). Br. J. Nutr. 30, 401.

Hoover, W. H. \& Heitmann, R. N. (1975). J. Nutr. 105, 245.

Just, A. (1980). Proc. Energy Metabolism. EAAP. Publ. 26, 27.

Just, A., Eggum, B. O., Jergensen, H. H. \& Jacobsen, I. (1977). Natl Inst. Anim. Sci. Copenhagen. Medd. 177.

Just, A., Sauer, W. C., Bech-Andersen, S., Jørgensen, H. H. \& Eggum, B. O. (1980). Z. Tierphysiol. Tierernähr. Futtermittelk. 43, 83 .

Just Nielsen, A. (1970). Natl Inst. Anim. Sci. Copenhagen, beretn 381.

Kennelly, J. J. \& Ahern, F. X. (1980). The 59th Annual Feeders' Day Report. Agriculture and Forestry Bulletin. Special Issue the University of Alberta. Canada: The University of Alberta.

McAtee, J. W., Little, C. O.\& Mitchell, G. E. Jr (1967). J. Anim. Sci. 26, 215 
Mason, V. C. (1980). In Current Concepts of Digestion and Absorption in Pigs [A. G. Low and I. G. Patridge, editors]. Reading: NIRD.

Mason, V. C. \& Just, A. (1976). Z. Tierphysiol. Tierernähr. Futtermittelk. 36, 301.

Michel, M. C. (1966). Annls Biol. Anim. Biochim. Biophys. 6, 33.

Neergaard, L., Petersen, C. B. \& Thorbek, G. (1969). Z. Tierphysiol. Tierernähr. Futtermittelk. $25,302$.

Payne, J. W. (1975). In Peptide Transport in Protein Nutrition, p. 283 [D. M. Mathews, editor]. Amsterdam: Elsevier.

Rerat, A. (1978). J. Anim. Sci. 46, 1808.

Rolls, B. A., Turvey, A. \& Coates, M. E. (1978). Br. J. Nutr. 39, 91.

Sambrook, I. E. (1979). Br. J. Nutr. 42, 267.

Stoldt, W. (1952). Fette Seifen, Anstrichm. 54, 206.

Thorbek, G. (1969). Natl Inst. Anim. Sci. Copenhagen. beretn 373.

Thorbek, G. (1975). Natl Inst. Anim. Sci. Copenhagen. beretn 424.

Thorbek, G. \& Henckel, S. (1976). Publs. Eur. Ass. Anim. Prod. 19, 117.

Vermorel, M. (1968). Annls Biol. Anim. Biochim. Biophys. 8, 453.

Weidner, K. \& Jakobsen, P. E. (1962). Dyrefysiologi II. Øvelsesvejledning for landbrugs-mejeribrugs- og licentiatstuderende ved Den kgl. Vet.- og Landbohøjskole. p. 118. K.V.L. Copenhagen: DSR-Forlag.

Wolstrup, J. \& Jensen, K. J. (1976). J. appl. Bact. $41,243$.

Yang, M. G., Manoharan, K. \& Michelsen, O. (1970). J. Nutr. 100, 545.

Zebrowska, T., Zebrowska, H. \& Buraczewska, L. (1980). 3rd Eur. Ass. Anim. Prod. Symp. Protein Metabolism and Nutrition, Braunschweig. 27, 222. 